\title{
Enhanced carbon overconsumption in response to increasing temperatures during a mesocosm experiment
}

\author{
J. Taucher ${ }^{1}$, K. G. Schulz ${ }^{1}$, T. Dittmar ${ }^{2}$, U. Sommer ${ }^{1}$, A. Oschlies ${ }^{1}$, and U. Riebesell ${ }^{1}$ \\ ${ }^{1}$ Helmholtz Centre for Ocean Research Kiel (GEOMAR), Kiel, Germany \\ ${ }^{2}$ Max-Planck Research Group for Marine Geochemistry, University of Oldenburg, Oldenburg, Germany \\ Correspondence to: J. Taucher (jtaucher@geomar.de)
}

Received: 8 March 2012 - Published in Biogeosciences Discuss.: 20 March 2012

Revised: 4 August 2012 - Accepted: 8 August 2012 - Published: 5 September 2012

\begin{abstract}
Increasing concentrations of atmospheric carbon dioxide are projected to lead to an increase in sea surface temperatures, potentially impacting marine ecosystems and biogeochemical cycling. Here we conducted an indoor mesocosm experiment with a natural plankton community taken from the Baltic Sea in summer. We induced a plankton bloom via nutrient addition and followed the dynamics of the different carbon and nitrogen pools for a period of one month at temperatures ranging from $9.5^{\circ} \mathrm{C}$ to $17.5^{\circ} \mathrm{C}$, representing a range of $\pm 4^{\circ} \mathrm{C}$ relative to ambient temperature. The uptake of dissolved inorganic carbon (DIC) and the net build-up of both particulate (POC) and dissolved organic carbon (DOC) were all enhanced at higher temperatures and almost doubled over a temperature gradient of $8^{\circ} \mathrm{C}$. Furthermore, elemental ratios of carbon and nitrogen $(\mathrm{C}: \mathrm{N})$ in both particulate and dissolved organic matter increased in response to higher temperatures, both reaching very high $\mathrm{C}: \mathrm{N}$ ratios of $>30$ at $+4{ }^{\circ} \mathrm{C}$. Altogether, these observations suggest a pronounced increase in excess carbon fixation in response to elevated temperatures. Most of these findings are contrary to results from similar experiments conducted with plankton populations sampled in spring, revealing large uncertainties in our knowledge of temperature sensitivities of key processes in marine carbon cycling. Since a major difference to previous mesocosm experiments was the dominant phytoplankton species, we hypothesize that species composition might play an important role in the response of biogeochemical cycling to increasing temperatures.
\end{abstract}

\section{Introduction}

Climate change is expected to affect marine ecosystems and biogeochemical cycling in the oceans in a variety of ways (Riebesell et al., 2009; IPCC, 2007a). Since the beginning of the 20th century, global average sea surface temperatures have already increased by $0.6^{\circ} \mathrm{C}$. Recent climate projections suggest an increase in global surface air temperatures by about 1.1 to $6.4^{\circ} \mathrm{C}$ by the end of this century (relative to 1980-1999), thereby also leading to a further warming of the upper ocean (IPCC, 2007b). This will affect marine ecosystems indirectly as thermal stratification of the water column becomes stronger, leading to changes in the availability of nutrients and light. It is also likely that sea surface warming will have pronounced direct effects on pelagic ecosystems and marine carbon cycling, as temperature is a major environmental factor controlling the rates of biological processes (Brown et al., 2004). Experimental evidence suggests a clear relationship between temperature and phytoplankton growth (Eppley, 1972).

A number of studies have already investigated the effects of increasing temperatures at the ecosystem level. Common observations were a decrease in body size of planktonic organisms (Moran et al., 2010; Daufresne et al., 2009), effects on timing of the bloom (Sommer and Lengfellner, 2008; Lassen et al., 2010), coupling of phytoplankton and bacterial processes (Hoppe et al., 2008), as well as changes in food web dynamics, i.e. a shift from autotrophic to more heterotrophic states of the respective ecosystems (Muren et al., 2005; O'Connor et al., 2009). In some of these experiments a lower overall biomass was found in response to warming (O'Connor et al., 2009; Lassen et al., 2010). 
However, most of these studies did not explicitly monitor biogeochemical dynamics. A recent mesocosm study with a natural plankton community investigated possible impacts of warming on biogeochemical cycling under spring bloom conditions (Wohlers et al., 2009). The results suggested an acceleration of respiratory carbon consumption over autotrophic production and an associated decrease in carbon drawdown at elevated temperatures. Furthermore, they found that warming shifted the partitioning of organic matter between the particulate and dissolved phase, with a higher fraction building up as dissolved material. This observation is also supported by another similar mesocosm experiment (Kim et al., 2011). Yet, little is known about whether these observed temperature sensitivities are a general pattern in marine ecosystems, or if the response of key processes in carbon cycling to sea surface warming depends on the phytoplankton assemblage. In both of the above mesocosm experiments, the dominant phytoplankton species was the diatom Skeletonema costatum. In this study, we investigated the effect of temperature changes on marine carbon cycling in a natural plankton community in summer and discuss differences with previous experiments.

\section{Material and methods}

\subsection{Experimental setup}

The indoor mesocosm study was carried out between 16 June and 16 July 2010 at the Helmholtz Centre for Ocean Research Kiel (GEOMAR) in Kiel, Germany. Nine cylindric mesocosms with a volume of 14001 (water depth: $\sim 100 \mathrm{~cm}$, diameter $\sim 140 \mathrm{~cm}$ ) each were set up in triplicates in three temperature controlled climate chambers, and filled simultaneously with unfiltered seawater from approximately $6 \mathrm{~m}$ depth in Kiel Fjord (Western Baltic Sea). Thus, the water in the mesocosms contained a natural summer plankton community representative for this region at that time.

Mesozooplankton (copepods of the species Acartia clausi) was added from net catches ( $64 \mu \mathrm{m}$ mesh size) with densities of $\sim 10$ individuals $1^{-1}$. Since Acartia clausi is the dominant mesozooplankton species $(>90 \%$ ) during most years in this region and the density of $10 \mathrm{ind}^{-1}$ is a reasonable number for this region and time of year (Behrends, 1996), we believe that our added mesozooplankton provides an adequate representation of field conditions.

To investigate the effects of temperature on a summer bloom situation, the temperatures in the three climate chambers were adjusted to $9.5^{\circ} \mathrm{C}, 13.5^{\circ} \mathrm{C}$ and $17.5^{\circ} \mathrm{C}$ (in the following referred to as "low", "intermediate" and "high" temperature, respectively). The intermediate temperature level of $13.5^{\circ} \mathrm{C}$ corresponded to the temperature of near-surface water $(\sim 5 \mathrm{~m}$ depth $)$ in the Kiel Fjord at the start of the experiment. The other temperature regimes were equivalent to in situ $+4{ }^{\circ} \mathrm{C}$ and in situ $-4{ }^{\circ} \mathrm{C}$, thereby establishing an over- all temperature gradient of $8^{\circ} \mathrm{C}$. Previous mesocosm experiments had only considered a temperature gradient in the direction of warming. In our experimental setup a temperature gradient towards both cooling and warming was established in order to ensure that the observed effects are truly associated with the absolute temperature and are not merely a stress response to a temperature change in either direction. Mesocosms had been filled one day before the experiment started $(t-1)$ as it took $\sim 24 \mathrm{~h}$ until target temperatures were reached. It should be noted that temperature regulation was not perfect with standard deviations between 0.4 and $0.8^{\circ} \mathrm{C}$ in the different treatments. This is mainly attributable to the experimental setup, i.e. the airflow in the climate chambers. Thereby, the temperature of one of the replicates was $\sim 1{ }^{\circ} \mathrm{C}$ lower than in the other two mesocosms at all temperatures. However, this variability within treatments is still much smaller than variability between treatments.

Light supply during the experiment was provided by a computer-controlled system, generating a light curve with a light/dark cycle of $\sim 17 / 7 \mathrm{~h}$. It contained full-spectrum light tubes $(12 \times 80 \mathrm{~W}$ per mesocosm; $10 \times 4000 \mathrm{~K}$ and $2 \times 9000 \mathrm{~K}$ color temperature) covering the full range of photosynthetically active radiation (PAR: 400-700 nm). The daily light dose was calculated for the respective latitude and day of the year following Brock (1981), resulting in a theoretical maximum irradiance intensity (at noon) of $\sim 690 \mathrm{~W} \mathrm{~m}^{-2}$ at the water surface. The actual target intensity was $32 \%$, corresponding to a daily maximum irradiance of $\sim 270 \mathrm{~W} \mathrm{~m}^{-2}$. However, the maximum realized intensity with our light supply was $\sim 80 \mathrm{~W} \mathrm{~m}^{-2}$ or $400 \mu$ mol photons $\mathrm{m}^{-2} \mathrm{~s}^{-1}$. Therefore, a plateau of maximum light intensity was established, holding the realized maximum light intensity long enough to compensate for the lack of desired maximum intensity. This way the desired integrated light supply of $\sim 1100 \mathrm{Wh} \mathrm{m}^{-2}$ could be achieved.

Measured concentrations of dissolved inorganic nutrients in the mesocosms on day $t 1$ amounted to $\sim 0.1 \mu \mathrm{mol} 1^{-1}$ phosphate $\left(\mathrm{PO}_{4}^{3-}\right), \quad \sim 1.5 \mu \mathrm{mol} 1^{-1}$ nitrate $\left(\mathrm{NO}_{3}^{-}\right)$, $\sim 0.4 \mathrm{~mol} \mathrm{l}^{-1}$ ammonium $\left(\mathrm{NH}_{4}\right)$ and $\sim 12.2 \mu \mathrm{mol} \mathrm{l}^{-1}$ silicate $\left(\mathrm{Si}(\mathrm{OH})_{4}\right)$. In order to initiate a phytoplankton bloom, inorganic nutrients were added to the mesocosms in Redfield stoichiometry on day $t 1$, with concentrations of $16.0 \mu \mathrm{moll}^{-1} \mathrm{NO}_{3}^{-}$and $1.0 \mu \mathrm{moll} 1^{-1} \mathrm{PO}_{4}^{3-}$. While these nutrient concentrations are not typical of summer conditions in the field, such nutrient pulses can regularly occur in summer in this region and induce summer plankton blooms, e.g. through wind-induced convective events (Carstensen et al., 2004). In our mesocosm experiment this nutrient addition was necessary to induce a plankton bloom with the processes and dynamics we intended to study in a time frame of weeks.

Throughout the experiment, the water in the mesocosms was gently mixed by attached propellers. This way, settling of particulate organic matter onto the bottom of the 
mesocosms was minimized as far as possible and a homogenous water body was maintained, allowing discrete water samples to be representative of the whole mesocosm. Therefore, this mixing should not be confused with convective mixing in the real ocean, as the mesocosms in our experiment were intended to mimic a water parcel in the surface ocean that would not mix with water from the deeper ocean.

After the addition of nutrients on 17 June $(t 1)$ the development and decline of the plankton bloom were followed over 30 days with samples being taken three times a week from intermediate depth with a silicon tube.

\subsection{Measurements}

Temperature, salinity and $\mathrm{pH}$ were measured with a WTW conductivity/pH probe (calibrated with NBS (National Bureau of Standards) buffer). Biomass estimates for community composition of phytoplankton are based on cell counts and cell volume conversion to carbon following Menden-Deuer and Lessard (2000). Samples for dissolved inorganic nitrate, nitrite, ammonium, phosphate and silicate were prefiltered through $0.2 \mu \mathrm{m}$ cellulose acetate filters and measured with an autoanalyzer (AA II) (Hansen and Koroleff, 2007).

Dissolved inorganic carbon (DIC) was measured spectrophotometrically on an autoanalyzer (Stoll et al., 2001). Samples were sterile filtered $(0.2 \mu \mathrm{m})$ and stored in borosilicate bottles, sealed with butyl/PTFE septa at temperatures below $10^{\circ} \mathrm{C}$ until analysis.

For the determination of particulate organic carbon and nitrogen (POC and PON), samples were filtered onto precombusted $\left(5 \mathrm{~h}\right.$ at $450^{\circ} \mathrm{C}$ ) glassfibre filters (Whatman, GF/F, $0.7 \mu \mathrm{m}$ nominal poresize), rinsed immediately after filtering of samples in order to avoid accumulation of DOM on the filters, and frozen (at $-20^{\circ} \mathrm{C}$ ) until analysis. POC filters were fumed overnight with hydrochloric acid $(37 \%)$ in order to remove particulate inorganic carbon (PIC) and dried at $60^{\circ} \mathrm{C}$ for approximately $12 \mathrm{~h}$. Afterwards they were analyzed on a Eurovector EuroEA-3000 elemental analyzer (Sharp, 1974).

Samples for dissolved organic carbon and total dissolved nitrogen (DOC and TDN) were filtered through precombusted GF/F filters, with the filtrate being collected in acidwashed $(\mathrm{HCl}, 10 \%)$ and precombusted $\left(12 \mathrm{~h}\right.$ at $\left.250^{\circ} \mathrm{C}\right)$ glass vials and frozen (at $-20^{\circ} \mathrm{C}$ ) until analysis. Prior to measurements, the $\mathrm{pH}$ was adjusted to $\mathrm{pH}=2$ with $\mathrm{HCl}$ (p.a.) and automatically purged with synthetic air in the DOC analyzer to remove inorganic carbon. The analysis was carried out by catalytic high-temperature combustion on a Shimadzu TOC-V analyzer with a total nitrogen module (TNM-1). The accuracy of the analysis was confirmed with deep-sea reference water samples provided by the University of Miami. The accuracy with respect to deep-sea water was within $5 \%$ relative error and detection limits were $5 \mu \mathrm{moll}^{-1}$ for DOC and $1 \mu \mathrm{mol} \mathrm{l}^{-1}$ for TDN. Procedural blanks did not yield detectable amounts of DOC and TDN. Dissolved organic nitrogen (DON) was calculated as the difference between TDN and the sum of all dissolved inorganic nitrogen species (nitrate, nitrite, and ammonium).

\subsection{Calculations}

Calculation of additional carbonate system variables (such as $p \mathrm{CO}_{2}$ ) from measured DIC and $\mathrm{pH}$ were carried out with the program CO2SYS (Lewis and Wallace, 1998), using the dissociation constants for carbonic acid as refitted by Dickson and Millero (1987). The $\mathrm{pH}$ values used for these calculations were measured on the NBS scale. The salinity of our seawater was $\sim 13$ and thus did not allow the use of certified reference buffers for calibration on the total scale. While we are aware that this might create electrode-specific uncertainties in measured $\mathrm{pH}$, it would not change the observed dynamics of calculated $p \mathrm{CO}_{2}$ over the course of the experiment, i.e. significantly lower minimum values at higher temperatures.

Air-water gas exchange of $\mathrm{CO}_{2}$ between mesocosms and atmosphere was estimated following the stagnant boundary layer model of Smith (1985), with molecular diffusivity calculated as described in Jähne et al. (1987) and a chemical enhancement factor derived from $\mathrm{pH}$ as in Kuss and Schneider (2004). The main equation used for gas exchange, following Smith (1985), is given by

$F=\frac{k \times K_{0} \times \Delta p \mathrm{CO}_{2} \times \text { area }_{\text {meso }}}{\text { volume }_{\text {meso }}}$.

In Eq. (1), $F$ is the air-water flux of $\mathrm{CO}_{2}$ and $k$ is the gas transfer velocity. The latter is a function of temperature and the thickness of the boundary layer, which in turn is a function of windspeed (Jähne et al., 1987). Furthermore, $K_{0}$ is the solubility of $\mathrm{CO}_{2}$ in water, with $K_{0}$ being a function of temperature and salinity, and $\Delta p \mathrm{CO}_{2}$ is the difference between partial pressure in water, calculated from measured $\mathrm{pH}$ and DIC and an assumed constant atmospheric value of $390 \mu$ atm.

However, this approach was originally developed for field conditions and not specifically for conditions such as those in our experimental setup, with constant mechanical mixing of the water column and a wind speed close to zero. Because of mixing-induced overturning of the water body, gas exchange is strongly underestimated when wind speed is set to zero in the calculations and mixing of the mesocosms is not accounted for. Without gas exchange, the amount of total carbon (DIC + POC + DOC) should not increase, as biological processes only lead to shifts between the different pools. Therefore, any change in total carbon concentrations is attributable to gas exchange, assuming no loss of carbon, e.g. through sinking. The temporal development of total carbon $(\mathrm{DIC}+\mathrm{POC}+\mathrm{DOC})$ in the mesocosms suggests a net carbon uptake of $\sim 200,310$ and $420 \mu \mathrm{mol} \mathrm{Cl}^{-1}$ at low, intermediate and high temperatures, respectively, over the course of the experiment (Fig. 4b). 
Equation (1) shows that the only way to account for the turnover of the water column through mechanical mixing is the adjustment of wind speed, and thereby the thickness of the boundary layer and the gas transfer velocity. To account for the observed increase in total carbon, wind speed was set to a value of $6 \mathrm{~m} \mathrm{~s}^{-1}$ in our calculations, yielding the best fit to the observed net carbon uptake (on day t30) in the mesocosms at different temperatures. Of course, this number for wind speed seems quite high for an indoor experiment, without any actual wind in our culture rooms. Even though mechanical mixing of the mesocosms does not lead to "surface roughness" as due to wind, the net effect of both mechanical mixing and wind mixing is the same: It leads to a rapid turnover of the water body. Thereby, the boundary layer, which is exchanging gas with the atmosphere, is constantly renewed and rapid air-water gas exchange is facilitated even at virtually zero wind speed. Consequently, our estimates of air-sea $\mathrm{CO}_{2}$ exchange are different from previous studies (Delille et al., 2005; Wohlers et al., 2009) that did not apply the modifications described above. Equation (1) also illustrates that the flux is dependent on the surfaceto-volume relationship of the mesocosms. The diameter of $\sim 140 \mathrm{~cm}$ is relatively high to the volume of 14001 (with $\sim 100 \mathrm{~cm}$ depth), thereby further facilitating high rates of gas exchange.

In fact, the magnitude of gas exchange in our mesocosm setup has been tested in a follow-up experiment, where the gas exchange of an injected tracer $\left(\mathrm{N}_{2} \mathrm{O}\right)$ was investigated in isolation, i.e. without the influence of biological processes (data not published yet). The results from that study support the high rates of gas exchange presented in this study and confirm that a parameterization of wind speed in the range of $4-8 \mathrm{~m} \mathrm{~s}^{-1}$ is necessary to account for the mechanical mixing of the mescosms and to explain the observed changes in the tracer.

Nutrient concentrations for day $t 0$ are estimated from data of day $t 1$, since sampling and measurements only started on day $t 1$, immediately prior to nutrient addition. These measurements revealed already slight differences between temperature treatments, which were probably caused by different biological activities at different temperatures. Concentrations of $\mathrm{NO}_{3}^{-}$on day $t 1$ ranged from $\sim 0.7$ to $2.6 \mu \mathrm{moll}^{-1}$ between warm and cold mesocosms. Since nutrient uptake was slowest in the colder mesocosms, we assumed the initial nutrient concentrations in all mesocosms on day $t 0$ to correspond to the concentrations in the low temperature treatment as the best approximation possible. For day $t 1$ the presented nutrient data was calculated as the sum of measured values and nutrient addition $\left(16.0 \mu \mathrm{mol} \mathrm{NO}_{3}^{-} 1^{-1}\right)$ for the respective mesocosms.

\subsection{Statistical analysis}

To test whether there are significant differences between the temperature treatments, a multivariate statistical analysis was carried out, as the different biogeochemical parameters are not independent from each other. Two-way ANOSIM (analysis of similarity) was applied on DIC, POC, DOC, $\mathrm{NO}_{3}$, $\mathrm{PON}$ and DON data to test whether there were significant differences between the temperature treatments and to illustrate the effect of time. Since we investigated dynamics during a plankton bloom, the biogeochemical parameters, and thus the effects of temperature, are of course strongly changing over time. This was also confirmed by the results of the two-way ANOSIM. Consequently, we additionally performed a oneway ANOSIM using only data from the day of the peak of the phytoplankton bloom $(t 12)$. To reveal which parameters were responsible for most of the differences between temperature treatments, a SIMPER (similarity percentages) analysis was carried out on the same datasets used for ANOSIM.

Furthermore, the effects of temperature on maximum drawdown of DIC, maximum build-up of POC and DOC, and maximum ratios of POC:PON and DOC:DON were analyzed with a linear regression model. This approach was chosen since it provides valuable quantitative information for ecological and biogeochemical modeling. Coefficients of determination $\left(R^{2}\right)$ and p-values of the applied regression models are given in the figure legends.

\section{Results}

\subsection{Bloom development and community composition}

At the beginning of the experiment, the phytoplankton community was composed of $\sim 54 \%$ diatoms and $\sim 46 \%$ cryptophytes in terms of biomass. After nutrient addition and with the onset of the bloom, diatoms became strongly dominant ( $>99 \%$ of biomass) in all mesocosms, in particular the species Dactyliosolen fragilissimus. Other functional groups (e.g. dinoflagellates) remained at very low abundances throughout the bloom $(<1 \%)$ and are thus likely negligible for the overall dynamics of the plankton bloom.

Copepod abundance remained approximately at initial levels of $\sim 10$ ind $^{-1}$ during the phytoplankton bloom in the first half of the experiment and was not affected by temperature (not shown). In the second half of the experiment, copepod numbers increased slightly and abundance of juveniles (copepodites) began to rise, indicating a stronger increase at lower temperatures (data not shown; manuscript in preparation).

The development of the phytoplankton bloom was characterized by a rapid decline in dissolved inorganic nutrients (Fig. 1), the drawdown of dissolved inorganic carbon and the build-up of particulate organic matter (Fig. 3). Temperature had a significant effect on all biogeochemical parameters over the course of the entire experiment (Table 1), most pronounced during the peak of the plankton bloom (Table 2). Most of the observed differences between the temperature 

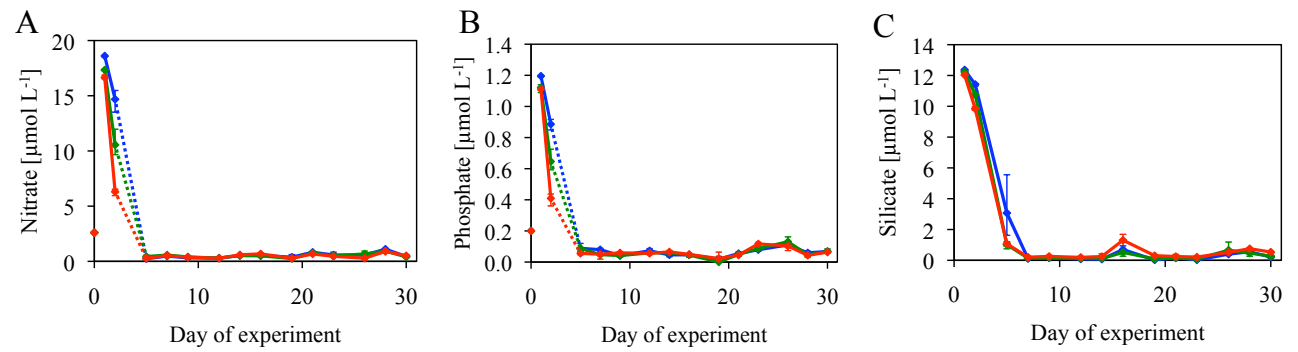

Fig. 1. Temporal development of (A) nitrate and (B) silicate in the mesocosms at low (blue), intermediate (green) and high (red) temperature. Vertical lines denote range of replicates within each temperature treatment.
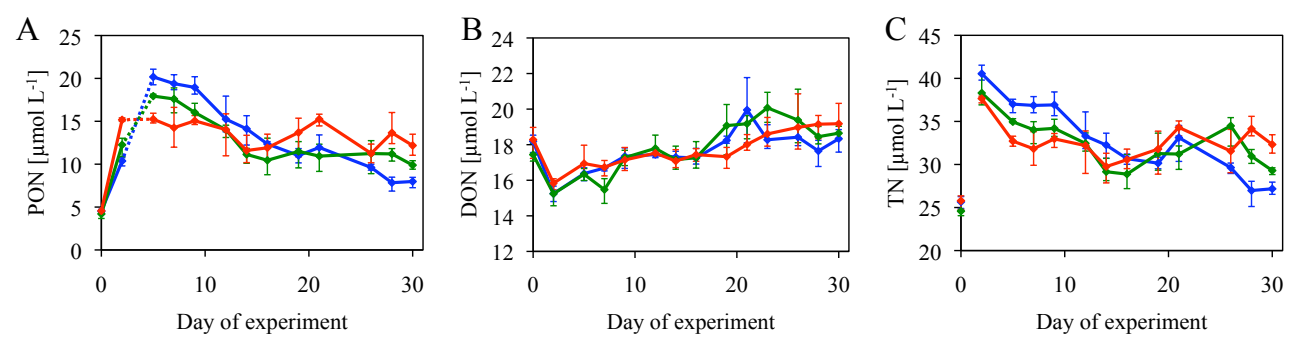

Fig. 2. Temporal development of (A) PON, (B) DON and (C) total nitrogen. Style and color-coding follow that of Fig. 1.

Table 1. Results of a two-way crossed ANOSIM of the effects of temperature and time on biogeochemical parameters (DIC, POC, DOC, $\mathrm{NO}_{3}, \mathrm{PON}$ and DON), including pairwise tests for differences between temperature treatments.

\begin{tabular}{lll}
\hline & $R$ & $p$ \\
\hline Overall (temperature) & 0.73 & $<0.01$ \\
Overall (time) & 0.69 & $<0.01$ \\
$18^{\circ} \mathrm{C}$ vs. $14^{\circ} \mathrm{C}$ & 0.56 & $<0.01$ \\
$18^{\circ} \mathrm{C}$ vs. $10^{\circ} \mathrm{C}$ & 0.95 & $<0.01$ \\
$14^{\circ} \mathrm{C}$ vs. $10^{\circ} \mathrm{C}$ & 0.73 & $<0.01$ \\
\hline
\end{tabular}

treatments (almost $90 \%$ ) could be explained by POC, DIC and DOC (Table 3).

Data shown in Figs. 1-3, 4a (upper panel), 4b and 5 are measured values. Data shown in Fig. 4a (lower panel), $4 \mathrm{c}$ and $4 \mathrm{~d}$ are based on carbonate system calculations (see Sect. 2.3).

\subsection{Nutrient consumption}

Calculated initial concentrations (on day $t 0$ ) of $\mathrm{NO}_{3}^{-}$and $\mathrm{PO}_{4}^{3-}$ in the mesocosms were 2.6 and $0.2 \mu \mathrm{moll}^{-1}$, respectively. Initial levels of silicate were $12.3 \mu \mathrm{moll}^{-1}$. With the addition of $16.0 \mu \mathrm{mol} \mathrm{NO} \mathrm{N}^{-} \mathrm{1}^{-1}$ and $1.0 \mu \mathrm{mol} \mathrm{PO}_{4}^{3-} 1^{-1}$, the total amount of available nutrients added up to $18.6 \mu \mathrm{mol} \mathrm{l}^{-1}$ for $\mathrm{NO}_{3}^{-}$and $1.2 \mu \mathrm{moll}^{-1}$ for $\mathrm{PO}_{4}^{3-}$. Following the addition of nitrate and phosphate on day $t 1$, inorganic nutrients were consumed very rapidly and were depleted in all mesocosms a few days after nutrient addition (Fig. 1). While both $\mathrm{NO}_{3}^{-}$and
Table 2. Results of a one-way ANOSIM of the effects of temperature on biogeochemical parameters (DIC, POC, DOC, $\mathrm{NO}_{3}, \mathrm{PON}$ and DON) at the time of the peak of the plankton bloom (day $t 12$ ), including pairwise tests for differences between temperature treatments.

\begin{tabular}{lll}
\hline For data from $t 12$ & $R$ & $p$ \\
\hline Overall & 0.84 & $<0.05$ \\
$18^{\circ} \mathrm{C}$ vs. $14^{\circ} \mathrm{C}$ & 0.78 & $<0.1$ \\
$18^{\circ} \mathrm{C}$ vs. $10^{\circ} \mathrm{C}$ & 1.00 & $<0.1$ \\
$14^{\circ} \mathrm{C}$ vs. $10^{\circ} \mathrm{C}$ & 0.74 & $<0.1$ \\
\hline
\end{tabular}

$\mathrm{PO}_{4}^{3-}$ were already exhausted on day $t 5$, the consumption of silicate was slightly slower, with exhaustion on day $t 7$. The depletion of silicate is in line with analysis of phytoplankton species composition, suggesting diatoms constituted a major fraction of phytoplankton biomass.

Nutrient concentrations on day $t 2$ of the experiment were lower in the mesocosms at higher temperatures, thus indicating a faster consumption with increasing temperatures. After reaching exhaustion on day $t 5$, concentrations of $\mathrm{NO}_{3}^{-}$stayed below $1.0 \mu \mathrm{moll}^{-1}$ and those of $\mathrm{PO}_{4}^{3-}$ below $0.1 \mu \mathrm{mol}{ }^{-1}$ for the rest of the experiment. Ammonium concentrations were almost constant and not affected by temperature, with concentrations in all mesocosms fluctuating between $\sim 0.2$ and $0.6 \mu \mathrm{mol}^{-1}$ throughout the experiment (not shown). 
Table 3. Results of a SIMPER analysis for the contributions of different biogeochemical variables to the differences between temperature treatments. Shown are biogeochemical variables that contribute to $90 \%$ of dissimilarity, with average concentration (square root transformed), average dissimilarity, ratio of average dissimilarity and respective standard deviation, as well as percentages of contribution and cumulative contribution. Average dissimiliarity between temperature treatments: $18^{\circ} \mathrm{C}$ and $14^{\circ} \mathrm{C}=5.30 ; 18^{\circ} \mathrm{C}$ and $10^{\circ} \mathrm{C}=7.08 ; 14^{\circ} \mathrm{C}$ and $10^{\circ} \mathrm{C}=5.32$.

\begin{tabular}{lrrrrrr}
\hline & $\begin{array}{r}\text { Avg. Conc. } \\
\text { (transformed) }\end{array}$ & $\begin{array}{r}\text { Avg. Conc. } \\
\text { (transformed) }\end{array}$ & $\begin{array}{c}\text { Avg. } \\
\text { Diss }\end{array}$ & Diss/SD. & Contrib. \% & Cum. \% \\
\hline POC & $18{ }^{\circ} \mathrm{C}$ & $14^{\circ} \mathrm{C}$ & & & & \\
$\mathrm{DIC}$ & 17.10 & 15.42 & 2.09 & 1.28 & 39.45 & 39.45 \\
$\mathrm{DOC}$ & 39.35 & 40.51 & 1.39 & 1.43 & 26.29 & 65.75 \\
$\mathrm{NO}_{3}$ & 22.02 & 20.71 & 1.20 & 1.40 & 22.53 & 88.28 \\
\hline & 0.82 & 0.90 & 0.27 & 0.61 & 5.04 & 93.32 \\
\hline $\mathrm{POC}$ & $1{ }^{\circ} \mathrm{C}$ & $10^{\circ} \mathrm{C}$ & & & & \\
$\mathrm{DIC}$ & 17.10 & 12.33 & 3.19 & 1.74 & 45.12 & 45.12 \\
$\mathrm{DOC}$ & 39.35 & 41.52 & 1.62 & 1.47 & 22.89 & 68.01 \\
$\mathrm{NO}$ & 22.02 & 19.56 & 1.55 & 1.72 & 21.86 & 89.86 \\
\hline & 0.82 & 3.57 & 0.32 & 1.63 & 4.55 & 94.41 \\
\hline $\mathrm{POC}_{3}$ & $14{ }^{\circ} \mathrm{C}$ & $10^{\circ} \mathrm{C}$ & & & & \\
$\mathrm{DIC}$ & 15.42 & 12.33 & 2.35 & 1.50 & 44.13 & 44.13 \\
$\mathrm{DOC}$ & 40.51 & 41.52 & 1.11 & 1.41 & 20.91 & 65.04 \\
$\mathrm{NO}_{3}$ & 20.71 & 19.56 & 1.08 & 1.37 & 20.25 & 85.28 \\
\hline
\end{tabular}

\subsection{Nitrogen}

After addition of inorganic nutrients, particulate organic nitrogen (PON) built up in all mesocosms from initial concentrations of $\sim 4.4 \mu \mathrm{mol} \mathrm{N}^{-1}$ to maximum concentrations of $\sim 20.2,17.9$ and $15.2 \mu \mathrm{mol} \mathrm{Nl^{-1 }}$ around day $t 5$ at low, intermediate and high temperatures, respectively (Fig. 2a). Accordingly, maximum build-up of PON was lower at higher temperatures. After the peak of the bloom, PON decreased in all mesocosms until the end of the experiment. PON concentrations at the end of the experiment were higher at elevated temperatures, reaching concentrations of $\sim 8.0,9.9$ and $12.2 \mu \mathrm{mol} \mathrm{N}^{-1}$ at low, intermediate and high temperatures, respectively.

Concentrations of dissolved organic nitrogen (DON) increased constantly throughout the experiment, reaching final concentrations of $\sim 18.7 \mu \mathrm{mol} \mathrm{N} 1^{-1}$ averaged over all mesocosms. An effect of temperature on the accumulation of DON could not be observed (Fig. 2b).

The total amount of nitrogen $(\mathrm{PON}+\mathrm{DON}+\mathrm{DIN}) \mathrm{de}-$ creased in all mesocosms over the course of the experiment (Fig. 2c). Initial concentrations were $\sim 25.4 \mu \mathrm{mol} \mathrm{N}^{-1}$ and maximum concentrations occurred one day after nutrient addition (day $t 2$ ) with $\sim 40.5,38.3$ and $37.7 \mu \mathrm{mol} \mathrm{N}^{-1}$ in the mesocosms at low, intermediate and high temperatures, respectively. During the bloom phase, total nitrogen decreased in all mesocosms (until $t 14$ to $t 16$ ). Afterwards, total nitrogen fluctuated strongly, reaching final concentrations (day t30) of $\sim 27.2,29.3$ and $32.3 \mu \mathrm{molN} 1^{-1}$ at low, intermediate and high temperatures, respectively. Thus, total nitrogen at the end of the experiment was higher at high temperatures, though this difference was pronounced only during the last few days of the experiment (Fig. 2c).

\subsection{Carbon}

\subsubsection{DIC uptake}

The consumption of inorganic nutrients was accompanied by photosynthetic uptake of dissolved inorganic carbon (DIC). Temporal dynamics of DIC concentrations showed a clear response to temperature, with average concentrations in the replicate mesocosms decreasing from initial levels of $\sim 1860 \mu \mathrm{mol}^{-1}$ on day $t 0$ to a minimum of $\sim 1590,1475$ and $1310 \mu \mathrm{mol}^{-1}$ until day $t 12$ at low, intermediate and high temperatures, respectively (Fig. 3a). This corresponds to a maximum DIC drawdown of $\sim 280 \mu \mathrm{mol} \mathrm{Cl}^{-1}$ on average at low, $390 \mu \mathrm{mol} \mathrm{Cl}^{-1}$ at intermediate, and $550 \mu \mathrm{mol} \mathrm{Cl} \mathrm{Cl}^{-1}$ at high temperatures (Fig. 3d). Accordingly, the magnitude of biologically mediated drawdown of DIC was significantly enhanced at higher temperatures. After the peak of the bloom, i.e. from day $t 12$ onwards, concentrations of DIC in the mesocosms increased again for the rest of the experiment, reaching approximately initial concentrations on day $t 30$.

When correcting for air-water gas exchange (see Sect. 2.3), the maximum uptake of DIC reached $\sim 380 \mu \mathrm{mol} \mathrm{Cl}^{-1}$ on average at low, $520 \mu \mathrm{mol} \mathrm{Cl}^{-1}$ at 

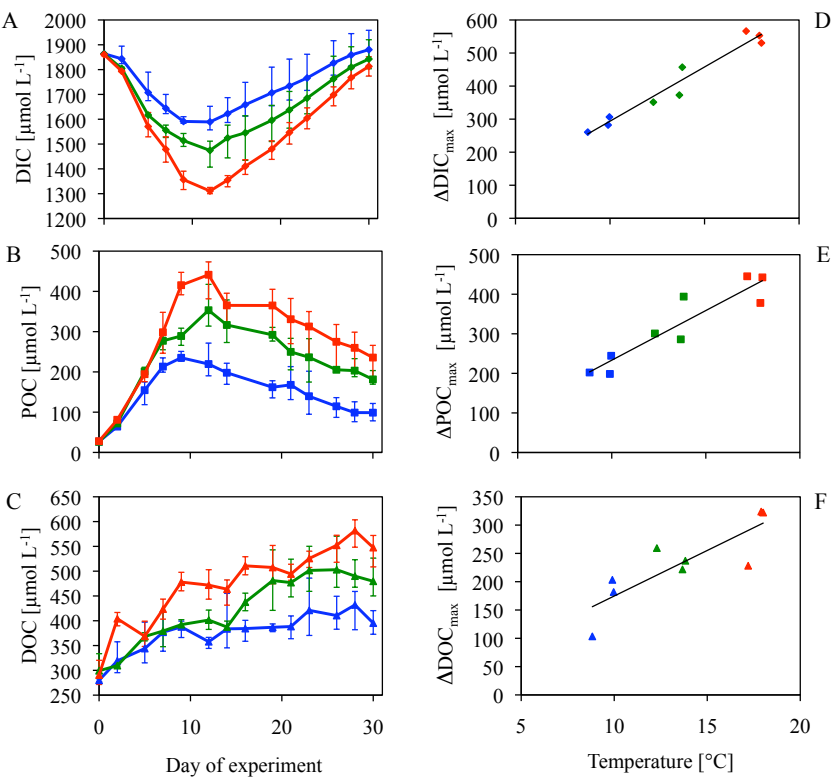

Fig. 3. Temporal development of measured concentrations of (A) DIC, (B) POC and (C) DOC. Style and color-coding follow that of Fig. 1. (D) Maximum drawdown in DIC, (E) maximum buildup of POC and (F) DOC as a function of temperature. Colorcoding as in Fig. 1. Solid lines denote linear regressions $(n=$ 9; $\Delta \mathrm{DIC}_{\max }: R^{2}=0.95, p<0.0001 ; \mathrm{POC}_{\max }: R^{2}=0.85, p<$ 0.0005; $\left.\Delta \mathrm{DOC}_{\max }: R^{2}=0.71, p<0.005\right)$.

intermediate, and $700 \mu \mathrm{molCl} \mathrm{Cl}^{-1}$ at high temperatures (Fig. 4a), corresponding to an increase in maximum DIC consumption of $\sim 40 \mu \mathrm{mol} \mathrm{Cl} 1^{-1}{ }^{\circ} \mathrm{C}^{-1}$. Accordingly, the rate of net DIC consumption during the bloom phase increased with higher temperatures, accelerating from an average of $\sim 32 \mu \mathrm{mol} \mathrm{Cl} l^{-1} \mathrm{~d}^{-1}$ in the cool mesocosms, to $44 \mu \mathrm{mol} \mathrm{Cl} l^{-1} \mathrm{~d}^{-1}$ at intermediate, and $56 \mu \mathrm{mol} \mathrm{Cl}^{-1} \mathrm{~d}^{-1}$ at high temperatures. This corresponds to a $Q_{10}$ value of $\sim 2.0$ for net DIC uptake.

\subsubsection{POC build-up}

The drawdown of DIC was reflected in a concomitant buildup of particulate organic carbon (POC), which peaked between days $t 9$ and $t 12$ in the different mesocosms (Fig. 3b). Starting from initial levels of $\sim 25-30 \mu \mathrm{mol} \mathrm{Cl} l^{-1}$, POC concentrations rapidly increased and reached maximum buildups of POC of $\sim 210 \mu \mathrm{mol} \mathrm{Cl}^{-1}$ at low, $325 \mu \mathrm{molCl}^{-1}$ at intermediate, and $410 \mu \mathrm{mol} \mathrm{Cl^{-1 }}$ at high temperatures. This corresponds to a linear increase of maximum POC build-

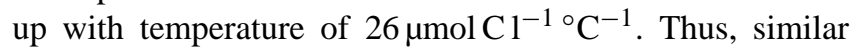
to DIC uptake, the magnitude of POC build-up was significantly elevated at higher temperatures (Fig. 3e). Accordingly, the rate of POC build-up during the bloom phase showed a clear response to higher temperatures, amounting to $\sim 22,27$ and $39 \mu \mathrm{mol} \mathrm{Cl}^{-1} \mathrm{~d}^{-1}$ at low, intermediate and high temper-

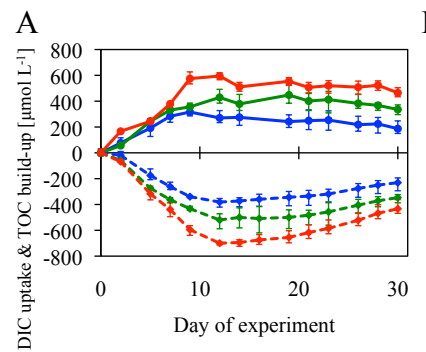

B
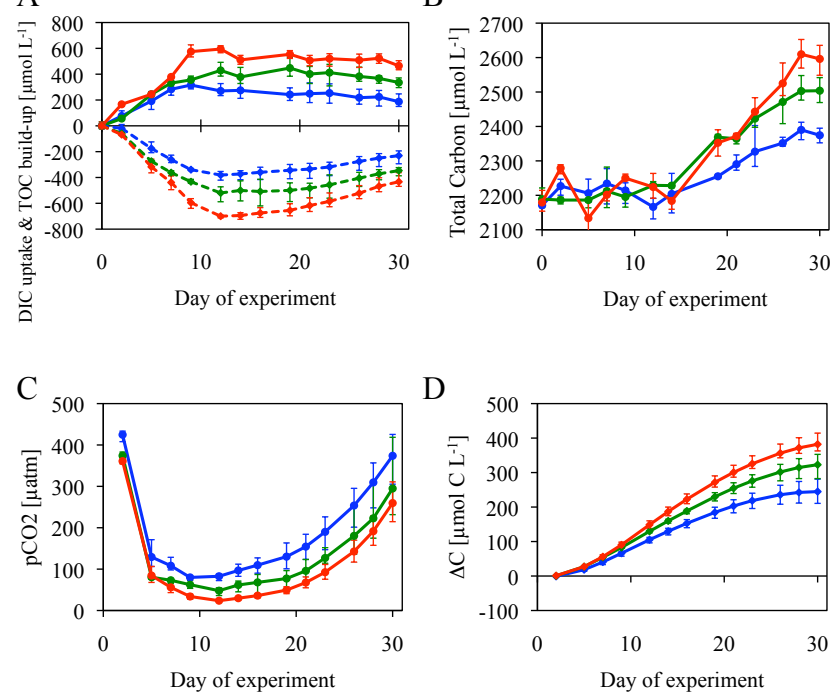

Fig. 4. Temporal development of (A) corrected (air-water gas exchange) DIC uptake (dashed) and measured TOC build-up (solid), (B) measured total carbon concentrations, (C) calculated $p \mathrm{CO}_{2}$ (water) in the mesocosms and (D) calculated cumulative air-water carbon flux into the mesososms. Style and color-coding follow that of Fig. 1.

atures, respectively. This corresponds to a $Q_{10}$ value of $\sim 2.0$ for net POC build-up.

After the peak of the bloom, POC concentrations in the water column decreased again. However, in contrast to DIC concentrations, POC did not reach initial levels but remained at concentrations much higher than at the beginning of the experiment.

\subsubsection{DOC accumulation}

Along with the decrease in DIC and build-up of POC, a substantial increase in dissolved organic carbon (DOC) was observed over the course of the experiment in all mesocosms (Fig. 3c). Starting from initial concentrations of $\sim 290 \mu \mathrm{mol} \mathrm{Cl}^{-1}$, DOC concentrations increased steadily over the course of the experiment, with maximum accumulation of DOC amounting to $\sim 160 \mu \mathrm{molCl}^{-1}$ at low, $240 \mu \mathrm{mol} \mathrm{Cl}^{-1}$ at intermediate, and $290 \mu \mathrm{mol} \mathrm{Cl}^{-1}$ at high temperatures. Thus, maximum build-up of DOC was significantly higher at elevated temperatures (Fig. 3f). This corresponds to a linear increase of maximum DOC accumulation of $16 \mu \mathrm{mol} \mathrm{Cl} \mathrm{C}^{-1}{ }^{\circ} \mathrm{C}^{-1}$. The rate of net DOC accumulation showed a positive relationship with temperature as well, increasing from an average of $3.8 \mu \mathrm{mol} \mathrm{Cl}^{-1} \mathrm{~d}^{-1}$ at low, to $6.0 \mu \mathrm{mol} \mathrm{Cl} \mathrm{l}^{-1} \mathrm{~d}^{-1}$ at intermediate, and $8.6 \mu \mathrm{mol} \mathrm{Cl}^{-1} \mathrm{~d}^{-1}$ at high temperatures. This increase corresponds to a $Q_{10}$ value of $\sim 2.7$ for the net build-up of DOC. 


\subsubsection{Carbon budget}

After the peak of the bloom, the amount of total organic carbon (TOC), i.e. the sum of particulate and dissolved organic carbon decreased relatively slowly and remained at levels much higher than initial concentrations until the end of the experiment (Fig. 4a). The decrease in POC was closely balanced by the increase in DOC, resulting in almost constant levels of TOC in the mesocosms at all temperatures. However, TOC concentrations after the bloom remained elevated at higher temperatures until the end of the experiment, amounting to $\sim 490,660$ and $780 \mu \mathrm{mol} \mathrm{Cl}^{-1}$ at low, intermediate and high temperature, respectively, on $t 30$.

In contrast to TOC, an increase of DIC concentrations began in all mesocosms with the decline of the bloom, with DIC approaching initial levels again at the end of the experiment (Fig. 3a). The phytoplankton bloom and the associated uptake of DIC were accompanied by a sharp decrease in the partial pressure of carbon dioxide $\left(p \mathrm{CO}_{2}\right)$ in the water. Early levels of calculated $p \mathrm{CO}_{2}$ (day $t 2$ ) were between $\sim 360$ and $430 \mu$ atm in all mesocosms, and thus near equilibrium with the atmosphere. Through biological uptake of DIC during the phytoplankton bloom, $p \mathrm{CO}_{2}$ dropped to minimum values of $\sim 78 \mu \mathrm{atm}$ at low, $45 \mu \mathrm{atm}$ at intermediate, and $24 \mu \mathrm{atm}$ at high temperatures in the relatively weakly buffered lowsalinity Baltic Sea water (Fig. 4c).

This gradient between $p \mathrm{CO}_{2}$ in water and air led to a flux of $\mathrm{CO}_{2}$ from the atmosphere into the water in all mesocosms. This $\mathrm{CO}_{2}$ flux was stronger in the mesocosms at higher temperatures, where more inorganic carbon had been taken up and converted to organic carbon and consequently higher airwater $p \mathrm{CO}_{2}$ gradients were reached (Fig. $4 \mathrm{c}$ and d). This fact is also reflected in the total amount of carbon (i.e. the sum of organic and inorganic carbon) in the mesocosms at the end of the experiment. Concentrations of total carbon on day $t 30$ were clearly elevated at higher temperatures, amounting to $\sim 2380,2500$ and $2600 \mu \mathrm{mol} \mathrm{Cl} \mathrm{l}^{-1}$ at low, intermediate and high temperatures, respectively (Fig. 4b). Furthermore, there is a positive effect of temperature on gas transfer velocity, enabling higher rates of gas exchange at higher temperatures $\left(\sim 25 \%\right.$ higher at $17.5^{\circ} \mathrm{C}$ than at $\left.9.5^{\circ} \mathrm{C}\right)$.

Our estimates of cumulative DIC increase due to air-water gas exchange suggest a clear effect of temperature, ranging from $\sim 240 \mu \mathrm{mol} \mathrm{Cl}^{-1}$ at low, to $\sim 320 \mu \mathrm{mol} \mathrm{Cl}^{-1}$ at intermediate, and $\sim 380 \mu \mathrm{mol} \mathrm{Cl}^{-1}$ at high temperatures over the course of the whole experiment (Fig. 4d).

\subsection{Stoichiometry}

\subsubsection{Drawdown of carbon and nitrogen}

While the same amount of $\mathrm{NO}_{3}^{-}$was consumed in the mesocosms at all temperatures $\left(\sim 18.3 \mu \mathrm{moll}^{-1}\right)$, the decrease in DIC concentrations and the calculated uptake of DIC (corrected for gas exchange) showed a significant increase with temperature (see Sect. 3.3.1). Accordingly, the ratio of maximum DIC uptake to the maximum consumption of $\mathrm{NO}_{3}^{-}$increased from $\sim 20.8$ at low, over 29.0 at intermediate, to 38.5 at high temperatures. This trend of increasing consumption of carbon over nitrogen at higher temperatures is reflected in the elemental ratios of particulate and dissolved organic matter (POM and DOM). Differential build-up and removal of particulate and dissolved organic matter led to temporal variations in the respective elemental ratios.

\subsubsection{C : N of POM}

The molar ratio of carbon to nitrogen $(\mathrm{C}: \mathrm{N})$ of particulate organic matter was $\sim 6.1$ in all mesocosms at the beginning of the experiment, and thereby close to the Redfield value of 6.6. From day $t 4$ on, POC:PON started to increase in all mesocosms, and showed a positive correlation with temperature (Fig. 5a). The maximum ratio of POC: PON was significantly enhanced at higher temperatures and reached 15.9 at low, 29.0 at intermediate, and 33.7 at high temperatures (Fig. $5 b ; p<0.0005$ ). After the decline of the bloom, POC : PON began to decrease again, however not back to initial values.

\subsubsection{C : N of DOM}

The elemental ratios of dissolved organic matter already deviated significantly from Redfield stoichiometry at the beginning of the experiment, with an average molar DOC:DON ratio of 16.1 over all mesocosms. $\mathrm{C}: \mathrm{N}$ ratios of DOM were steadily increasing before, during and after the phytoplankton bloom over the entire course of the experiment, showing clear differences between temperature treatments (Fig. 5c). The maximum ratio of DOC: DON was significantly affected by temperature and reached 25.6 at low, 28.1 at intermediate, and 30.8 at high temperatures (Fig. $5 \mathrm{~d} ; p<0.005$ ).

\section{Discussion}

\subsection{Budgets of nitrogen and carbon}

\subsubsection{Loss of organic matter}

The temporal development of total nitrogen $(\mathrm{PON}+\mathrm{DON}+\mathrm{DIN})$ suggests a loss of organic matter over the course of the experiment. Total nitrogen decreased in all mesocosms by $\sim 8.4 \mu \mathrm{mol} \mathrm{N1} \mathrm{l}^{-1}$, most pronounced during the first half of the experiment until day $t 14$ (Fig. 2c).

In mesocosm experiments, organic matter can potentially get lost through wall growth or sinking of organic matter to the bottom of the mesocosms. However, it is difficult to quantify the proportional effect of these mechanisms for the observed loss in our experiment. Based on repeated inspections, no visible growth of algae could be found on the mesocosm walls. Furthermore, using a similar experimental setup, 
Sommer et al. (2007) concluded that it takes 7-8 weeks until the development of wall growth plays a significant role. On the other hand, the sedimentation of particles to the bottom of the mesocosms cannot be ruled out. Previous studies have shown, that sinking of organic matter can lead to a considerable loss of biomass from the surface layer in mesocosm experiments (Keller et al., 1999; Wohlers et al., 2009). Since high concentrations of POC and PON were reached very rapidly in our experiment, it is possible that some of this newly produced biomass sunk to the bottom of the mesocosms. Although mixing of the water column by the propeller should minimize particle settling, this can obviously never be excluded entirely, and it can be assumed that the loss of organic matter would have been much higher without any mixing of the water in the mesocosms. Possibly the formation of fast sinking aggregates played an important role in this regard. This mechanism could also explain why the loss of organic matter differed among the different temperature treatments. Higher build-up of DOM and extracellular gel-particles (TEP) at higher temperatures might have facilitated particle aggregation (Burd and Jackson, 2009; Passow, 2002), thereby leading to a larger sinking loss of organic matter in the warmer mesocosms. While we did not measure TEP in our experiment, $\mathrm{POC}$ and POC : PON data suggest that TEP might have contributed substantially to the observed POC dynamics (see Sect. 4.2.1). Furthermore, other loss terms that could be potentially responsible for a loss of nitrogen can be excluded. It is very unlikely that denitrification occurred in the well-mixed (and thus well- oxygenated) mesocosms, and the data does not suggest a significant contribution of degassing of regenerated ammonium. Therefore, sinking of particles is likely to be the dominant mechanism for the observed loss of organic matter.

\subsubsection{Air-water gas exchange}

Without external sources or sinks, the amount of total carbon $(\mathrm{DIC}+\mathrm{POC}+\mathrm{DOC})$ in the mesocosms would be constant, as biological processes do not influence the overall mass balance of carbon but only shift matter between the different pools. If at all, one would expect a loss of total carbon in such an experiment, e.g. through wall growth or sinking of organic matter to the bottom of the mesocosms (see Sect. 4.1.1). However, we observed a strong increase of total carbon in the mesocosms, with clearly elevated concentrations at higher temperatures at the end of the experiment (Fig. 4b). Accordingly, this increase in total carbon could only be attributable to an external input of carbon into the mesocosms, which was only possible through continuous and rapid air-water gas exchange of $\mathrm{CO}_{2}$ in our experiment. Due to the rapid decrease in $p \mathrm{CO}_{2}$ associated with DIC uptake (Fig. 4c), a considerable air-water flux of $\mathrm{CO}_{2}$ started with the onset of the bloom and prevailed for the rest of the experiment (see Sect. 3.4.4 and Fig. 4a). High rates of gas exchange were facilitated through continuous mixing of the water col-
A

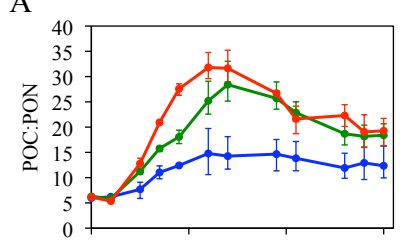

B
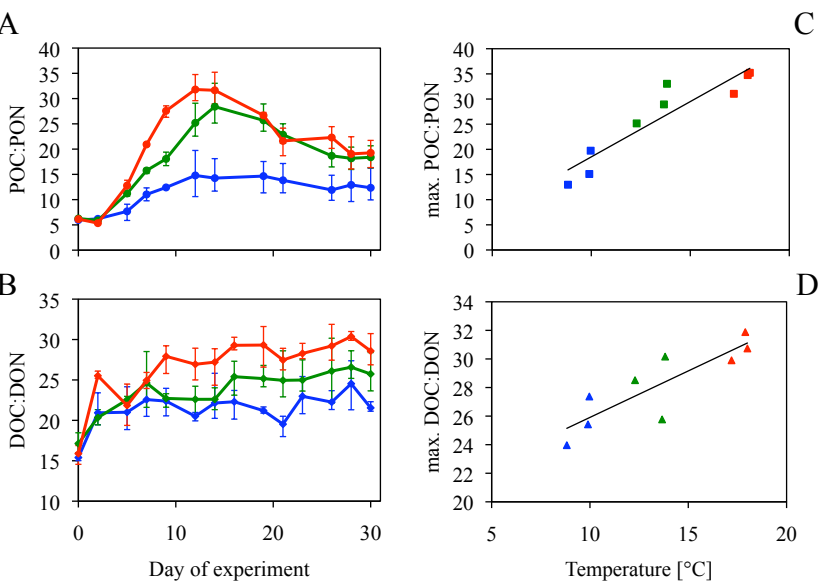

Fig. 5. Temporal development of $\mathrm{C}: \mathrm{N}$ in (A) particulate and (B) dissolved organic matter. Maximum $\mathrm{C}: \mathrm{N}$ of (C) particulate and (D) dissolved organic matter as a function of temperature. Style and color-coding follow that of Fig. 3. Solid lines denote linear regressions $\left(n=9\right.$; POC: $\mathrm{PON}_{\max }: R^{2}=0.86, p<0.0005$; DOC $\left.: \mathrm{DON}_{\max }: R^{2}=0.73, p<0.005\right)$.

umn by propellers attached to the mesocosms. Thereby, the boundary layer that exchanges gas with the atmosphere was constantly renewed and rapid air-water gas exchange was facilitated (see Sect. 2.3). Since more DIC was consumed and converted to organic matter during the bloom phase at higher temperatures, the air-water difference in $p \mathrm{CO}_{2}$ and the magnitude of gas exchange were also enhanced at higher temperatures. The positive effect of temperature on gas transfer velocity additionally facilitated gas exchange at higher temperatures. Consequently, temperature affected carbon uptake by the water column in two ways: directly, by enhancing the gas transfer velocity, and indirectly, by enhancing biological carbon drawdown and the associated effect on $p \mathrm{CO}_{2}$.

It is very likely that the observed loss of nitrogen was accompanied by a corresponding loss of carbon in the first half of the experiment. If the $\mathrm{C}: \mathrm{N}$ of the missing fraction of total $\mathrm{N}$ is comparable to the $\mathrm{C}: \mathrm{N}$ of organic matter that was identified, another substantial amount of carbon is also missing in the total carbon (DIC + POC + DOC). The delay between rapidly decreasing seawater $p \mathrm{CO}_{2}$ levels and the increase in total carbon in the mesocosms supports this assumption, since an increase in total carbon should have been immediately visible with the onset of air-water gas exchange (Fig. $4 \mathrm{~b}$ and d). Consequently, this loss of carbon is not taken into account for the estimate of gas exchange, which is based only on the observable increase in total carbon. Therefore, actual gas exchange could have been even higher but was compensated by the loss of carbon in the first half of the experiment (approximately until day $t 14$ ). The calculated uptake of DIC through gas exchange (until $t 14$ ), which did not translate into an observed increase in total carbon concentration and by inference an estimate for the loss of organic 
carbon, amounts to $\sim 100,120$ and $180 \mu \mathrm{mol} \mathrm{Cl} \mathrm{Cl}^{-1}$ at low, intermediate and high temperatures, respectively (Fig. $4 \mathrm{~b}$ and d). However, an even higher input of carbon through gas exchange would be necessary to account for the observed loss of nitrogen $\left(\sim 8.4 \mu \mathrm{mol} \mathrm{N} 1^{-1}\right)$, assuming $\mathrm{C}: \mathrm{N}$ ratios of measured POM of up to $>30$. Since our estimate of gas exchange neglects this potential loss of carbon due to settling of particles and/or TEP in the initial phase of the experiment, it can, in this respect, be regarded as a conservative estimate for airsea carbon flux.

Even though gas exchange had a substantial effect on measured concentrations of DIC, and a certain amount of organic matter may have been lost during the experiment, our results do not indicate a relevant influence of these processes on our main conclusions, i.e. the temperature sensitivity of carbon overconsumption and the build-up of POC and DOC (see Sects. 4.2 and 4.3).

\subsection{Carbon overconsumption and temperature}

\subsubsection{Dynamics of DIC and particulate organic matter}

Our results suggest a positive effect of temperature not only on the relative consumption of DIC over nutrients, but also on the build-up and elemental ratios of POM for the plankton community in our experiment. Especially after nutrient depletion, strong differences in POC dynamics occurred between the different temperature treatments (Fig. 3b), revealing a clear effect of temperature on the POC:PON ratio (Fig. 5a and c). It has to be noted that the observed temporal dynamics in POC: PON might be partly attributable to different concentrations of PON that were affected by possibly differential loss of organic matter (see Sect. 4.1.1). However, the major differences in POC: PON occurred between $t 12$ and $t 14$, when the differences in PON among the temperature treatments had become very small again and differences in POC were the main driver for differences in POC: PON.

The main mechanism responsible for the higher uptake of DIC and build-up of organic carbon at higher temperatures in our experiment was the higher relative consumption of carbon over nitrogen and its associated conversion to biomass. Excess uptake of DIC over inorganic nitrogen, a phenomenon called carbon overconsumption (Toggweiler, 1993), has been observed in previous experiments and field studies. Some earlier studies which found enhanced drawdown of carbon over nitrogen did not find changes in POC : PON as in our experiment (Banse, 1994; Riebesell et al., 2007). Instead, a common assumption was that the excess carbon is exuded by phytoplankton mainly in the form of DOC (Kähler and Koeve, 2001). However, in agreement with our study, an increasing number of studies have reported a decoupling of carbon and nitrogen dynamics in phytoplankton blooms and an associated increase of the POC : PON ratio (Wetz and Wheeler, 2003; Biddanda and Benner, 1997; Engel et al., 2002). Generally, elemental stoichiometry of phy- toplankton and POM can vary widely, depending on nutrient status and environmental conditions (Geider and La Roche, 2002; Finkel et al., 2010). An increasing cellular quota of carbon to nitrogen in phytoplankton has been found for different species under nutrient limitation (Harrison et al., 1977; Goldman et al., 1992), and there is also evidence for an influence of temperature on intracellular $\mathrm{C}: \mathrm{N}$ ratios, at least for some species (Thompson et al., 1992; Berges et al., 2002). Hence, this mechanism might have contributed to the high $\mathrm{C}: \mathrm{N}$ ratios of POM in our experiment.

Since an increase in POC:PON is usually observed after nutrient exhaustion, carbon overconsumption is commonly assumed to be associated with nutrient stress (Biddanda and Benner, 1997; Wetz and Wheeler, 2003). This is in line with the observations in our experiment: While PON reached its highest levels at the same time as nutrients were exhausted (day $t 5$ ), minimum levels of DIC and maximum concentrations of POC occurred much later (between day $t 9$ and $t 11$ ). Furthermore, the major differences in drawdown of DIC and build-up of POC and DOC among the different temperature treatments occurred after nutrient depletion (Fig. 5). These observations further support the major role of excess carbon fixation for biogeochemical dynamics and its response to increasing temperatures in our experiment.

Engel et al. (2002) also observed an increase in POC: PON, which they concluded to be attributable to excess carbon fixation. However, they found a significant portion of excess carbon fixation to be channeled into the pool of transparent extracellular particles (TEP). Since we observed a massive build-up of POC and an associated strong increase in POC:PON, it is likely that at least part of these dynamics are attributable to the accumulation of carbon-rich (and nitrogen-poor) extracellular organic matter. This consideration is also supported by the strong build-up of dissolved organic matter in our experiment, as previous studies have shown that a considerable fraction of excess POC can be associated with TEP that form from dissolved polysaccharides (Engel et al., 2004). The transformation of DOC into extracellular POC via aggregation of TEP has been shown before in experimental studies (Mopper et al., 1995), and the underlying mechanisms have already been investigated and discussed (Passow, 2002). Furthermore, it is unlikely that the increase in POC : PON is entirely attributable to changes in the elemental composition of phytoplankton. Intracellular $\mathrm{C}: \mathrm{N}$ ratios of diatoms are usually $<10$ (Thompson et al., 1992; Goldman et al., 1992) and do not exceed a value of 15 even under nutrient starvation (Harrison et al., 1977). Thus, we believe that the accumulation of carbon-enriched extracellular particles is the most likely explanation for the strong decoupling of POC and PON in our experiment.

An effect of temperature on the magnitude of POC production and POC : PON resulting from carbon overconsumption as observed in our experiment has, to the best of our knowledge, not been reported so far. Nor did previous mesocosm experiments (Wohlers et al., 2009) find an 
effect of temperature on POC: PON. It is also notable, that POC : PON reached very high absolute values in comparison to previous studies (between 16 and 34 at temperatures ranging from 9.5 to $17.5^{\circ} \mathrm{C}$ ). This suggests relatively high levels of carbon overconsumption, which increase with temperature.

Furthermore, results from single-species culture experiments suggest that TEP production is highly variable between phytoplankton species and that it is a function of temperature (Claquin et al., 2008). Accordingly, species-specific differences in TEP production could also contribute to the observed differences in carbon dynamics between our and earlier mesocosm experiments.

Differences in POC and the POC : PON ratio did not occur when nutrients were still replete. Thus, our results are in line with previous studies that did not observe an effect of temperature on $\mathrm{C}: \mathrm{N}$ ratios in exponentially growing cultures, i.e. under nutrient-replete conditions (Hutchins et al., 2007; Hare et al., 2007; Feng et al., 2009). Since carbon overconsumption is usually closely tied to nutrient-limited growth, and our results suggest that the main effects of temperature in our experiment were related to this process, it can be hypothesized that the implications of our results are mainly important in advanced or declining plankton blooms.

These conclusions are not affected by our estimates of gas exchange. Since the amount of inorganic nitrogen was similar in all mesocosms, the temperature-related difference in inorganic carbon drawdown (from raw DIC data, Fig. 3a) alone supports the hypothesized temperature effect on carbon overconsumption. This is further supported by the presented data on POC and DOC, as well as the $\mathrm{C}: \mathrm{N}$ ratios of particulate and dissolved organic matter. Air-water gas exchange only enhances the magnitude of DIC uptake in the mesocosms.

\subsubsection{Dynamics of dissolved organic matter}

Another remarkable observation in our experiment was the substantial build-up of DOC and its clear relationship with temperature. While the dynamics of DON did not show any response to temperature (Fig. 2b), the accumulation of DOC was clearly enhanced at higher temperatures (Fig. 3c and f), with the maximum build-up of DOC being enhanced by $+47 \%$ and $+79 \%$ at intermediate and high temperatures, respectively, compared to low temperatures.

Net accumulation of DOC usually occurs when biological production and loss processes are temporarily decoupled, which often happens in phytoplankton blooms (Carlson, 2002). A large portion of up to $50 \%$ of primary production can be channeled into the DOC pool (Hansell et al., 2009). The release of DOC by phytoplankton is generally assumed to increase with the onset of nutrient limitation (Biddanda and Benner, 1997). However, only a few studies on the influence of temperature on DOC production exist, and the results from single-species experiments are controversial. While Verity (1981) could not observe an effect of tem- perature on dissolved primary production after acclimatization, Zlotnik and Dubinsky (1989) found clearly higher DOC excretion with increasing temperatures. However, they used different phytoplankton species in their studies. More recent findings from short-term warming experiments with natural plankton communities support the latter study, suggesting an increase of dissolved primary production at elevated temperatures (Moran et al., 2006). This is in line with the observed effect of temperature on net DOC accumulation in our experiment and other recent mesocosm studies (Wohlers et al., 2009; Engel et al., 2011; Kim et al., 2011). Thus, our results strongly support the assumption that phytoplankton exudation of DOM is temperature sensitive.

The ratio of DOC:DON also increased with temperature in our experiment, suggesting enhanced exudation of DOC over DON by phytoplankton at higher temperatures (Fig. 5d). Since a temperature effect on autotrophic production is also mirrored in the response of POC and POC: $\mathrm{PON}$ to higher temperatures, enhanced release of carbon-enriched DOM by phytoplankton due to carbon overconsumption is the most likely explanation for the observed dynamics of DOC accumulation and the DOC: DON ratio.

The net accumulation of DOC throughout the experiment (Fig. 3c) and the relative constancy of TOC after the peak of the bloom (Fig. 4b) did not indicate any substantial decrease of organic matter through microbial consumption. Unfortunately, bacterial production was not measured in our experiment, making it impossible to give statements about gross rates. Thus, there is a possibility that microbial consumption of organic matter occurred, and that it was approximately balanced by production. On the other hand, inhibition of microbial degradation of DOC might also explain our finding. This has been observed before, e.g. due to high resistance of fresh DOC to microbial decomposition (Fry et al., 1996) or nutrient limitation by bacteria leading to inefficient bacterial decomposition (Thingstad et al., 1997). Further factors such as the molecular weight and chemical composition of DOM play a crucial role in its availability for bacterial degradation, although there are still huge gaps in our understanding of these aspects (Dittmar and Paeng, 2009).

\subsection{Why is the response to temperature changes so different from previous experiments?}

Temperature is a key factor in controlling ecological processes through its effect on metabolic rates (Brown et al., 2004). Our study revealed a strong effect of temperature on the dynamics of particulate organic matter, which was not observed in previous experiments. Most comparable studies investigating effects of temperature on marine ecosystems report negative impacts of increasing temperatures, e.g. on production of biomass derived from cell counts (O'Connor et al., 2009; Lassen et al., 2010; Muren et al., 2005) as well as on the build-up of measured POC (Wohlers et al., 2009; Kim et al., 2011). In contrast, both the magnitude and the rate 
of POC build-up were considerably elevated at higher temperatures in our experiment. Maximum build-up of POC increased by $+52 \%$ and $+96 \%$ at intermediate and high, compared to low temperatures, respectively. The calculated $Q_{10}$ value of $\sim 2.0$ for the rate of POC build-up in our experiment lies at the upper end of estimates for the temperature dependence of autotrophic processes such as phytoplankton growth and photosynthesis $\left(1<Q_{10}<2\right)$, which are also limited by light and nutrients (Eppley, 1972). The net build-up of DOC, which likely originates from exudation by phytoplankton, revealed an even higher effect of temperature $\left(Q_{10} \sim 2.7\right)$. This tendency of enhanced DOC accumulation at elevated temperatures (Fig. 3f) is in line with results from previous mesocosm studies (Wohlers et al., 2009; Kim et al., 2011). Our results suggest that these high $Q_{10}$ values are mainly attributable to the temperature sensitivity of carbon overconsumption by phytoplankton and could hence be interpreted as net $Q_{10}$ factors for processes related to excess carbon fixation.

The previously reported shift from autotrophy to heterotrophy in response to warming (Wohlers et al., 2009; O'Connor et al., 2009; Muren et al., 2005) and an associated decrease in overall biomass could not be observed in our experiment. Wohlers et al. (2009) found a lower consumption of DIC at elevated temperatures (decrease of up to $-31 \%$ when increasing temperature by $2-6^{\circ} \mathrm{C}$ ), which they attributed mainly to a stronger effect of warming on respiratory consumption relative to autotrophic production. Such an effect could not be observed in our experiment, where the drawdown of DIC was strongly enhanced at higher temperatures $(+39 \%$ and $+94 \%$, Fig. $3 \mathrm{a}$ and b). Possibly, the temperature effect on carbon overconsumption and DOC exudation prevented a substantial imbalance between production and consumption of organic matter in our experiment.

Altogether, our results revealed a fundamentally different response of carbon cycling to sea surface warming compared to earlier studies. Consequently, the question is why our results are so different to those of previous studies.

One possible explanation for the different temperature sensitivity of biogeochemical dynamics might be the taxonomic composition of the phytoplankton assemblage prior to the bloom and especially the dominant species. At the beginning of our experiment (day $t 0$ ) it consisted of $\sim 53 \%$ diatoms and $47 \%$ cryptophytes in terms of biomass. After nutrient addition diatoms dominated the phytoplankton bloom (>99\%), which is in line with previous mesocosm experiments (Kim et al., 2011; Wohlers et al., 2009). However, the prevailing diatom species was different to that in these previous studies. While Skeletonema costatum dominated in the two earlier experiments, Dactyliosolen fragilissimus was the dominant species in our experiment, constituting 80-99\% of phytoplankton biomass. It has been shown in a number of studies that different diatom species can have different cellular composition and produce different amounts of extracellular carbohydrates. (Wetz and Wheeler, 2003, 2007;
Goldman et al., 1992; Myklestad, 1974). Furthermore, differences in the response to changing temperatures among diatom species have been observed. While reports on possible temperature effects on the cellular composition of diatoms are contradictory (Montagnes and Franklin, 2001), the release of DOC (Zlotnik and Dubinsky, 1989) and production of TEP (Claquin et al., 2008) seem to increase with temperature.

Although no study on the physiology of Dactyliosolen fragilissimus and the mechanisms related to carbon overconsumption exists to the best of our knowledge, we hypothesize that physiological properties of this dominant phytoplankton species (e.g. carbon fixation, exudation of DOM and TEP, intracellular $\mathrm{C}: \mathrm{N}$ ) could be decisive for the response of the whole ecosystem, and may thus explain the different response to temperature changes compared to previous experiments. This is supported by the fact that the bloom was strongly dominated by this single species, and other mechanisms such as grazing dynamics appear to be of minor importance in our experiment and do not seem to deviate substantially from earlier studies.

The abundance of the copepod Acartia clausi was rather low and very similar at all temperatures during the bloom phase $\left(\sim 10\right.$ individuals $\left.1^{-1}\right)$ when the major differences in carbon and nitrogen cycling occurred. Even though copepod numbers slightly increased and the abundance of juveniles (copepodites) began to rise during the second half of the experiment (manuscript in preparation), copepod grazing cannot explain the large differences in element cycling between our temperature treatments. Assuming typical values for grazing rates $\left(0.1-0.5 \mu \mathrm{mol} \mathrm{Cind}{ }^{-1} \mathrm{~d}^{-1}\right)$ and body mass (3-5 $\mu \mathrm{g} \mathrm{C}_{\text {ind }}^{-1}$ ) of Acartia clausi (Fileman et al., 2010), we estimate that copepod grazing effects are too small to substantially affect biogeochemical dynamics, e.g. the loss of organic matter or temperature-related differences in POC and DOC concentrations.

The overall higher temperatures in our experiment might also have contributed to the differences with previous experiments. Higher temperatures and associated higher levels of metabolic rates might have revealed temperature effects on processes such as carbon overconsumption that could not be found in previous experiments at lower temperatures, where these processes might have been inhibited or temperaturedriven differences were too small to be detected. Furthermore, the present study had higher light levels compared to previous experiments, as it was intended to mimic the summer conditions in the field at the time of the experiment. This may have additionally favored excess carbon fixation of phytoplankton, since exudation of DOC has been observed to increase with irradiance (Verity, 1981; Zlotnik and Dubinsky, 1989). Possibly, these different boundary conditions also contributed to the response of biogeochemical element cycling to temperature in our experiment. 


\section{Conclusions}

The balance between build-up and decline of organic matter in the surface ocean plays a major role in marine biogeochemical cycling, as it strongly affects the uptake and sequestration of carbon and other elements to the deep ocean. The present study revealed large uncertainties in our knowledge of temperature sensitivities of key processes in marine carbon cycling.

Our results show that increasing temperatures can have previously unconsidered effects on the build-up of organic matter and uptake of carbon dioxide by marine ecosystems. The response of some processes was contrary to previous experiments, suggesting that temperature effects on biogeochemical cycling are potentially dependent on the composition of the phytoplankton assemblage. Especially processes such as carbon overconsumption and exudation of DOM seem to be highly temperature sensitive and might play an important role in the ecosystem response to temperature changes, i.e. under future sea surface warming or in past cooler times, such as glacial periods. This could not only alter the balance between production and consumption of organic matter, but also the partitioning between particulate and dissolved organic matter and their respective elemental composition and carbon uptake under changing temperatures.

Thus, our findings also imply further challenges for ecosystem modeling and climate change projections. Only little attention has been paid to the effects of increasing temperatures on biological processes in global warming simulations. Current representations of temperature sensitivity differ greatly among marine ecosystem models. Consequently, it is currently not possible to forecast how the effect of future sea surface warming on marine carbon cycling might look like on a global scale (Taucher and Oschlies, 2011). Furthermore, our study clearly shows that increasing sea surface temperatures might have substantial impacts on marine ecosystems and that we do not even know the direction in which some key physiological and ecosystem processes will respond under future warming. We therefore conclude that temperature effects on these processes require further research, both in experimental and modeling studies, in order to improve our understanding of possible impacts of sea surface warming on marine biogeochemical cycling.
Acknowledgements. This study was supported by Deutsche Forschungsgemeinschaft (DFG). Furthermore, we thank Aljoša Zavišić for assistance with POC and PON measurements, Jana Meyer for assistance with DIC measurements, Matthias Friebe for technical assistance with DOC and TDN analysis, Bente Gardeler for measurements of inorganic nutrients and Jamileh Javidpour for organizing and coordinating the mesocosm experiment. We also thank David Hutchins and two anonymous reviewers for their constructive comments.

The service charges for this open access publication have been covered by a Research Centre of the Helmholtz Association.

Edited by: C. Robinson

\section{References}

Banse, K.: Uptake of inorganic carbon and nitrate by marine plankton and the Redfield ratio, Global Biogeochem. Cy., 8, 81-84, 1994.

Behrends, G.: Long-term investigations of seasonal mesozooplankton dynamics in Kiel Bight, Germany, Jurmala, Latvia (1993), Proc. 13th BMB Symp., 1996.

Berges, J. A., Varela, D. E., and Harrison, P. J.: Effects of temperature on growth rate, cell composition and nitrogen metabolism in the marine diatom Thalassiosira pseudonana (Bacillariophyceae), Mar. Ecol.-Prog. Ser., 225, 139-146, doi:10.3354/meps225139, 2002.

Biddanda, B. and Benner, R.: Carbon, nitrogen, and carbohydrate fluxes during the production of particulate and dissolved organic matter by marine phytoplankton, Limnol. Oceanogr., 42, 506518, 1997.

Brock, T. D.: Calculating solar radiation for ecological studies, Ecol. Model., 14, 1-19, doi:10.1016/0304-3800(81)90011-9, 1981.

Brown, J. H., Gillooly, J. F., Allen, A. P., Savage, V. M., and West, G. B.: Toward a metabolic theory of ecology, Ecology, 85, 17711789, 2004.

Burd, A. B. and Jackson, G. A.: Particle Aggregation, in: Annual Review of Marine Science, Annual Review of Marine Science, Annual Reviews, Palo Alto, 1, 65-90, 2009.

Carlson, C. A.: Production and Removal Processes, in: Biogeochemistry of Marine Dissolved Organic Matter, edited by: Dennis, A. H. and Craig, A. C., Academic Press, San Diego, 91-151, 2002.

Carstensen, J., Conley, D. J., and Henriksen, P.: Frequency, composition, and causes of summer phytoplankton blooms in a shallow coastal ecosystem, the Kattegat, Limnol. Oceanogr., 49, 191201, 2004.

Claquin, P., Probert, I., Lefebvre, S., and Veron, B.: Effects of temperature on photosynthetic parameters and TEP production in eight species of marine microalgae, Aquat. Microb. Ecol., 51, 1-11, doi:10.3354/ame01187, 2008.

Daufresne, M., Lengfellner, K., and Sommer, U.: Global warming benefits the small in aquatic ecosystems, P. Natl. Acad. Sci. USA, 106, 12788-12793, doi:10.1073/pnas.0902080106, 2009.

Delille, B., Harlay, J., Zondervan, I., Jacquet, S., Chou, L., Wollast, R., Bellerby, R. G. J., Frankignoulle, M., Borges, A. V., Riebe- 
sell, U., and Gattuso, J. P.: Response of primary production and calcification to changes of $p \mathrm{CO}_{2}$ during experimental blooms of the coccolithophorid Emiliania huxleyi, Global Biogeochem. Cy., 19, Gb2023, doi:10.1029/2004gb002318, 2005.

Dickson, A. G. and Millero, F. J.: A comparison of the equilibrium constants for the dissociation of carbonic acid in seawater media, Deep-Sea Res., 34, 1733-1743, doi:10.1016/01980149(87)90021-5, 1987.

Dittmar, T. and Paeng, J.: A heat-induced molecular signature in marine dissolved organic matter, Nat. Geosci., 2, 175-179, doi:10.1038/ngeo440, 2009.

Engel, A., Goldthwait, S., Passow, U., and Alldredge, A.: Temporal decoupling of carbon and nitrogen dynamics in a mesocosm diatom bloom, Limnol. Oceanogr., 47, 753-761, 2002.

Engel, A., Delille, B., Jacquet, S., Riebesell, U., Rochelle-Newall, E., Terbruggen, A., and Zondervan, I.: Transparent exopolymer particles and dissolved organic carbon production by Emiliania huxleyi exposed to different $\mathrm{CO}_{2}$ concentrations: a mesocosm experiment, Aquat. Microb. Ecol., 34, 93-104, 2004.

Engel, A., Handel, N., Wohlers, J., Lunau, M., Grossart, H. P., Sommer, U., and Riebesell, U.: Effects of sea surface warming on the production and composition of dissolved organic matter during phytoplankton blooms: results from a mesocosm study, J. Plankton Res., 33, 357-372, doi:10.1093/plankt/fbq122, 2011.

Eppley, R. W.: Temperature and phytoplankton growth in sea, Fish. B.-NOAA, 70, 1063-1085, 1972.

Feng, Y. Y., Hare, C. E., Leblanc, K., Rose, J. M., Zhang, Y. H., DiTullio, G. R., Lee, P. A., Wilhelm, S. W., Rowe, J. M., Sun, J., Nemcek, N., Gueguen, C., Passow, U., Benner, I., Brown, C., and Hutchins, D. A.: Effects of increased $p \mathrm{CO}_{2}$ and temperature on the North Atlantic spring bloom, I. The phytoplankton community and biogeochemical response, Mar. Ecol.-Prog. Ser., 388, 13-25, doi:10.3354/meps08133, 2009.

Fileman, E., Petropavlovsky, A., and Harris, R.: Grazing by the copepods Calanus helgolandicus and Acartia clausi on the protozooplankton community at station L4 in the Western English Channel, J. Plankton Res., 32, 709-724, doi:10.1093/plankt/fbp142, 2010.

Finkel, Z. V., Beardall, J., Flynn, K. J., Quigg, A., Rees, T. A. V., and Raven, J. A.: Phytoplankton in a changing world: cell size and elemental stoichiometry, J. Plankton Res., 32, 119-137, doi:10.1093/plankt/fbp098, 2010.

Fry, B., Hopkinson, C. S., and Nolin, A.: Long-term decomposition of DOC from experimental diatom blooms, Limnol. Oceanogr., 41, 1344-1347, 1996.

Geider, R. J. and La Roche, J.: Redfield revisited: variability of $\mathrm{C}: \mathrm{N}: \mathrm{P}$ in marine microalgae and its biochemical basis, Eur. J. Phycol., 37, 1-17, doi:10.1017/s0967026201003456, 2002.

Goldman, J. C., Hansell, D. A., Dennett, M. R.: Chemical characterization of three large oceanic diatoms: potential impact on water column chemistry, Mar. Ecol.-Prog. Ser., 88, 257-270, 1992.

Hansell, D. A., Carlson, C. A., Repeta, D. J., and Schlitzer, R.: Dissolved organic matter in the ocean - A controversy stimulates new insights, Oceanography, 22, 202-211, 2009.

Hansen, H. P. and Koroleff, F.: Determination of nutrients, Methods of Seawater Analysis, Wiley-VCH Verlag GmbH, 159-228, 2007.

Hare, C. E., Leblanc, K., DiTullio, G. R., Kudela, R. M., Zhang, Y., Lee, P. A., Riseman, S., and Hutchins, D. A.: Consequences of increased temperature and $\mathrm{CO} 2$ for phytoplankton community structure in the Bering Sea, Mar. Ecol.-Prog. Ser., 352, 9-16, doi:10.3354/meps07182, 2007.

Harrison, P. J., Conway, H. L., Holmes, R. W., and Davis, C. O.: Marine diatoms grown in chemostats under silicate or ammonium limitation, 3. Cellular chemical composition and morphology of Chaetoceros debilis, Skeletonema costatum, and Thalassiosira gravida, Mar. Biol., 43, 19-31, 1977.

Hoppe, H. G., Breithaupt, P., Walther, K., Koppe, R., Bleck, S., Sommer, U., and Jurgens, K.: Climate warming in winter affects the coupling between phytoplankton and bacteria during the spring bloom: a mesocosm study, Aquat. Microb. Ecol., 51, 105115, doi:10.3354/ame01198, 2008.

Hutchins, D. A., Fu, F. X., Zhang, Y., Warner, M. E., Feng, Y., Portune, K., Bernhardt, P. W., and Mulholland, M. R.: $\mathrm{CO}_{2}$ control of Trichodesmium $\mathrm{N}_{2}$ fixation, photosynthesis, growth rates, and elemental ratios: Implications for past, present, and future ocean biogeochemistry, Limnol. Oceanogr., 52, 1293-1304, doi:10.4319/lo.2007.52.4.1293, 2007.

IPCC: Climate Change 2007: Impacts, Adaptation and Vulnerability. Contribution of Working Group II to the Fourth Assessment Report of the Intergovernmental Panel on Climate Change, edited by: Parry, M. L., Canziani, O. F., Palutikof, J. P., van der Linden, P. J. and Hanson, C. E., Cambridge University Press, Cambridge, UK, 976 pp., 2007a.

IPCC: Climate Change 2007: The Physical Science Basis. Contribution of Working Group I to the Fourth Assessment Report of the Intergovernmental Panel on Climate Change., edited by: Solomon, S., Qin, D., Manning, M., Chen, Z., Marquis, M., Averyt, K. B., Tignor, M. and Miller, H. L., Cambridge University Press, Cambridge, United Kingdom and New York, NY, USA, 996 pp., 2007 b.

Jähne, B., Heinz, G., and Dietrich, W.: Measurement of the Diffusion Coefficients of Sparingly Soluble Gases in Water, J. Geophys. Res., 92, 10767-10776, doi:10.1029/JC092iC10p10767, 1987.

Kähler, P. and Koeve, W.: Marine dissolved organic matter: can its $\mathrm{C}: \mathrm{N}$ ratio explain carbon overconsumption?, Deep-Sea Res. Pt. I, 48, 49-62, 2001.

Keller, A. A., Oviatt, C. A., Walker, H. A., and Hawk, J. D.: Predicted impacts of elevated temperature on the magnitude of the winter-spring phytoplankton bloom in temperate coastal waters: A mesocosm study, Limnol. Oceanogr., 44, 344-356, 1999.

Kim, J. M., Lee, K., Shin, K., Yang, E. J., Engel, A., Karl, D. M., and Kim, H. C.: Shifts in biogenic carbon flow from particulate to dissolved forms under high carbon dioxide and warm ocean conditions, Geophys. Res. Lett., 38, L08612, doi:10.1029/2011g1047346, 2011.

Kuss, J., and Schneider, B.: Chemical enhancement of the $\mathrm{CO}_{2}$ gas exchange at a smooth seawater surface, Mar. Chem., 91, 165174, doi:10.1016/j.marchem.2004.06.007, 2004.

Lassen, M. K., Nielsen, K. D., Richardson, K., Garde, K., and Schluter, L.: The effects of temperature increases on a temperate phytoplankton community - A mesocosm climate change scenario, J. Exp. Mar. Biol. Ecol., 383, 79-88, doi:10.1016/j.jembe.2009.10.014, 2010.

Lewis, E. and Wallace, D. W. R.: Program developed for $\mathrm{CO}_{2}$ system calculations (Internet), ORNL/CDIAC-105, Oak Ridge (Tennessee): Carbon Dioxide Information Analysis Center, US 
Department of Energy, available at: http://cdiac.ornl.gov/ftp/ co2sys (last access: October 2011), 1998.

Menden-Deuer, S. and Lessard, E. J.: Carbon to volume relationships for dinoflagellates, diatoms, and other protist plankton, Limnol. Oceanogr., 45, 569-579, 2000.

Montagnes, D. J. S. and Franklin, D. J.: Effect of temperature on diatom volume, growth rate, and carbon and nitrogen content: Reconsidering some paradigms, Limnol. Oceanogr., 46, 20082018, 2001.

Mopper, K., Zhou, J. A., Ramana, K. S., Passow, U., Dam, H. G., and Drapeau, D. T.: The role of surface-active carbohydrates in the flocculation of a diatom bloom in a mesocosm, Deep-Sea Res. Pt. II, 42, 47-73, 1995.

Moran, X. A. G., Sebastian, M., Pedros-Alio, C., and Estrada, M.: Response of Southern Ocean phytoplankton and bacterioplankton production to short-term experimental warming, Limnol. Oceanogr., 51, 1791-1800, 2006.

Moran, X. A. G., Lopez-Urrutia, A., Calvo-DÍaz, A., and Li, W. K. W.: Increasing importance of small phytoplankton in a warmer ocean, Global Change Biol., 16, 1137-1144, doi:10.1111/j.13652486.2009.01960.x, 2010.

Muren, U., Berglund, J., Samuelsson, K., and Andersson, A.: Potential effects of elevated sea-water temperature on pelagic food webs, Hydrobiologia, 545, 153-166, doi:10.1007/s10750-0052742-4, 2005.

Myklestad, S.: Production of carbohydrates by marine planktonic diatoms. I. Comparison of nine different species in culture, J. Exp. Mar. Biol. Ecol., 15, 261-274, doi:10.1016/00220981(74)90049-5, 1974.

O'Connor, M. I., Piehler, M. F., Leech, D. M., Anton, A., and Bruno, J. F.: Warming and Resource Availability Shift Food Web Structure and Metabolism, Plos Biol., 7, e1000178, doi:10.1371/journal.pbio.1000178, 2009.

Passow, U.: Transparent exopolymer particles (TEP) in aquatic environments, Prog. Oceanogr., 55, 287-333, 2002.

Riebesell, U., Schulz, K. G., Bellerby, R. G. J., Botros, M., Fritsche, P., Meyerhofer, M., Neill, C., Nondal, G., Oschlies, A., Wohlers, J., and Zollner, E.: Enhanced biological carbon consumption in a high $\mathrm{CO}_{2}$ ocean, Nature, 450, 545-548, doi:10.1038/Nature06267, 2007.

Riebesell, U., Kortzinger, A., and Oschlies, A.: Sensitivities of marine carbon fluxes to ocean change, P. Natl. Acad. Sci. USA, 106, 20602-20609, doi:10.1073/pnas.0813291106, 2009.

Sharp, J. H.: Improved Analysis for "Particulate" Organic Carbon and Nitrogen from Seawater, Limnol. Oceanogr., 19, 984-989, 1974.
Smith, S. V.: Physical, chemical and biological characteristics of $\mathrm{CO}_{2}$ gas flux across the air-water interface, Plant Cell Environ., 8, 387-398, doi:10.1111/j.1365-3040.1985.tb01674.x, 1985.

Sommer, U. and Lengfellner, K.: Climate change and the timing, magnitude, and composition of the phytoplankton spring bloom, Global Change Biol., 14, 1199-1208, doi:10.1111/j.13652486.2008.01571.x, 2008.

Sommer, U., Aberle, N., Engel, A., Hansen, T., Lengfellner, K., Sandow, M., Wohlers, J., Zollner, E., and Riebesell, U.: An indoor mesocosm system to study the effect of climate change on the late winter and spring succession of Baltic Sea phytoand zooplankton, Oecologia, 150, 655-667, doi:10.1007/s00442006-0539-4, 2007.

Stoll, M. H. C., Bakker, K., Nobbe, G. H., and Haese, R. R.: Continuous-Flow Analysis of Dissolved Inorganic Carbon Content in Seawater, Anal. Chem., 73, 4111-4116, doi:10.1021/ac010303r, 2001.

Taucher, J. and Oschlies, A.: Can we predict the direction of marine primary production change under global warming?, Geophys. Res. Lett., 38, L02603, doi:10.1029/2010g1045934, 2011.

Thingstad, T. F., Hagstrom, A., and Rassoulzadegan, F.: Accumulation of degradable DOC in surface waters: Is it caused by a malfunctioning microbial loop?, Limnol. Oceanogr., 42, 398-404, 1997.

Thompson, P. A., Guo, M.-X., and Harrison, P. J.: Effects of variation in temperature. I. On the biochemical compostion of eight species of marine phytoplankton, J. Phycol., 28, 481-488, doi:10.1111/j.0022-3646.1992.00481.x, 1992.

Toggweiler, J. R.: Carbon overconsumption, Nature, 363, 210-211, 1993.

Verity, P. G.: Effects of temperature, irradiance, and daylength on the marine diatom Leptocylindrus danicus Cleve. II. Excretion, J. Exp. Mar. Biol. Ecol., 55, 159-169, doi:10.1016/00220981(81)90109-x, 1981.

Wetz, M. S. and Wheeler, P. A.: Production and partitioning of organic matter during simulated phytoplankton blooms, Limnol. Oceanogr., 48, 1808-1817, 2003.

Wetz, M. S. and Wheeler, P. A.: Release of dissolved organic matter by coastal diatoms, Limnol. Oceanogr., 52, 798-807, 2007.

Wohlers, J., Engel, A., Zollner, E., Breithaupt, P., Jurgens, K., Hoppe, H. G., Sommer, U., and Riebesell, U.: Changes in biogenic carbon flow in response to sea surface warming, P. Natl. Acad. Sci. USA, 106, 7067-7072, doi:10.1073/pnas.0812743106, 2009.

Zlotnik, I. and Dubinsky, Z.: The effect of light and temperature on DOC excretion by phytoplankton, Limnol. Oceanogr., 34, 831839, 1989. 